\title{
INTERPRETING ISLAM AND PLURAL SOCIETY
}

\author{
Muhammad Haniff Hassan*
}

\begin{abstract}
This article seeks to provide a descriptive and analytical perspective about how Islam can be interpreted by Muslims in plural societies with two contrasting results. Building on those results, this article provides two other variations, thus providing a spectrum of views on Islam and a plural society in one continuum. The article also offers an extrapolation of Muslim attitudes and treatment of nonMuslims in two different contexts; where Muslims are a majority group or as a minority in a non-Muslim country. The two contexts are chosen because they represent the contemporary setting, in which many Muslims find themselves today. Finally, the article offers some reasons that explain the divergence of views and sometimes even contradicting interpretations that influence and shape Muslim attitudes towards plural societies.
\end{abstract}

\section{Introduction}

The post 9/11 period has witnessed an increase of interest in the Islamic world, although scholarship about Islam and Muslims has existed for hundreds of years. One topic that has received major attention in the backdrop of the 'Global War on Terror' concerns Islam and tolerance, as well as the attitude of Muslims towards other cultures.

This article seeks to provide a descriptive and analytical perspective of how Islam can be interpreted by Muslims living in plural societies with two contrasting results. It will then build on these results two other variations, thus providing a spectrum of views on Islam in relation to a plural society in one continuum. The article also offers an extrapolation of Muslim attitudes and their approach toward non-Muslims in two different contexts: when they constitute the majority group in a Muslim country and when they are a minority in a non-Muslim country. These two contexts were selected because they represent the contemporary setting that many Muslims are facing today. Finally, the article also seeks to explain the divergence of views and sometimes even contradictory interpretations that influence and shape Muslim attitudes towards plural or multicultural societies.

* Muhammad Haniff Hassan is an Associate Research Fellow and a PhD research student at the S. Rajaratnam School of International Studies (RSIS), Nanyang Technological University, Singapore. 
It is hoped that this explanation will provide insights into the dynamics and divergences of the various schools of thought held on this issue within the Muslim world, which will then help to provide better understanding and appreciation about Islam and Muslims. By understanding the ideas that underline Muslim behaviour, one will be better prepared to relate with Muslims, develop policies concerning them and counter any intolerant ideas that may hold, among many other possible benefits.

In the context of this article it must be stressed that the term 'plural society' is defined as a society that is composed of diverse ethnic, cultural and religious groups. The word 'plural' is used for its generic interpretation as covering various forms of diversity such as multi-cultural, multi-ethnic and multi-religious societies; i.e., the social contexts that this article wishes to cover.

\section{Islam and Plural Society: The Negative Viewpoint}

The first view to be explored holds that Islam promotes a negative attitude towards plural society.

There is a contradiction between the fundamental teachings of Islam and a plural society. The proponents of this viewpoint hold that Islam's fundamentals require Muslims to believe that their faith is the only religion recognised by God (Qur'ān 3:19, 85), ${ }^{1}$ as a religion for all mankind (39:3). Hence kufr (disbelief) is the gravest $\sin$ in the eye of God $(31: 13 ; 4: 48 ; 98: 6 ; 5: 72 ; 18: 110)$ as Muslims are commanded to 'enjoin good and forbid evil' $(3: 104,110)$. The Muslim attitude towards evil is thus stipulated by the Prophet: "Anyone among you, who sees disobedience towards God (munkar), should change it with his hand. If he is not able to do so, then with his tongue. If he is not able to do so, then he should change it in his heart. And that is the weakest of faith." There is no good that is greater than bringing people to the fold of Islam and there is no greater evil that Muslims must combat than disbelief. This view holds that allowing non-Muslims to practise their religions freely in the public is a negation to the command that all mankind must submit to the God of Islam (51:56). A plural society, however, necessitates tolerance as a public manifestation of other faiths. It follows then that Muslims living in a plural society have to tolerate 'evil' practices in the public, which is in contradiction with the Prophet's injunction above. As for allowing propagation of other faiths in the public, it is tantamount to endorsing kufr (disbelieving), and this must be prevented as it could lead to apostasy among Muslims, which is strictly forbidden. The free public propagation of other 'false' faiths represents a direct challenge to Islam which cannot be allowed. ${ }^{2}$

1. Qur'ān 3:19 and 85.

2. Muḥammad Sa ‘̄̄d Salīm al-Qahțānī, Al-Walā' wa'l-barā' fì'l-Islām (Riyadh: Dār al-Ṭayyibah, Riyadh, 1404/1983), 352-3. 
The Ultimatum: Embrace Islam, submit to Islam's rule or risk war. The revelation of Chapter 9 of the Qur'ān contains verses that call upon Muslims to wage unconditional war against non-Muslims. According to the proponents of this view, this in itself abrogates all verses on jih $\bar{a} d$ for pure self-defence, patience and tolerance towards non-Muslims. ${ }^{3}$ Verse 5 of this chapter stipulates that all peace treaties with pagan Arabs are null and void and that they should be given no other option other than to embrace Islam or face war. Verse 29 of the same chapter allows a special concession for non-Muslims to remain with their faith, but only if they agree to submit under the rule of Islam. The practice of issuing such 'ultimatums' can also be seen in many hadīths. One hadīth records the Prophet's instruction to his military commanders:

Fight with the name of God and in the path of God. Combat those who disbelieve in God. Fight, yet do not cheat, do not break trust, do not mutilate, do not kill minors. If thou encounter an enemy from among the associators [infidels], then offer them three alternatives. Whichever of these they may accept, agree to it and withhold thyself from them: So call upon them to embrace Islam. If they accept, then agree to it and withhold thyself from them. Then ask them to quit their territory in order to immigrate into the territory of the migrants [i.e. the Muslim state], and inform them that if they do that they will have same rights as the migrants and same obligations as they. If they refuse to migrate, then inform them that they will be considered as Bedouin [nomadic, sic!] Muslims, the same divine laws being obligatory on them as on other believers, except that they will not benefit by booty and other state income unless they join forces and fight along the Muslims. If, however, they refuse, then call them to pay jizyah ['protection tax']. If they accept, then agree to it and withhold thyself from them. If they refuse, then seek help from God and combat them $[\ldots]{ }^{4}$

3. "Declaration of War Against Americans Occupying the Land of the Two Holy Places", PBS Online Newshour, available online at http://www.pbs.org/newshour/terrorism/international/fatwa_1996. html (accessed on 22 August 2008) [first published by Al Quds Al Arabi, a London-based newspaper in August 1996]; "World Islamic Front Statement on Jihad Against Jews and Crusaders", Al Quds Al Arabi (23 February 1998), available online at http://www.fas.org/irp/world/para/docs/980223fatwa.htm (accessed on 22 August 2008); Tayseer Alouni's interview with Usāmah bin Lāden, Al-Jazeera, October 2001; Text of Al-Qaeda's statement, Associated Press, 9 October 2001; Sout Al-Jihad 3, 1424/2003, 18, 25-30; Muhammad 'Abd al-Salām al-Farj, Al-Jihād: Al-Farị̄ah alghā'ibah, available at http://e-prism.org/images/ALFAREDA.doc (accessed on 4 February 2008), 16. Al-Farj was a leader of the Egyptian Islamic Jihad Organisation, to which Ayman al-Zawāhirī also belonged before its merger with Al-Qaeda. The book was the organisation's primary reference of its ideology; Al-Qaeda in Iraq, "Limādha nuqātil? Man nuqātil?", available at http://tawhed. ws/r?i=3421 (accessed on 4 February 2008); Hamd b. 'Abd Allāh Al-Humaydī, Hattā lā tasm' li'l-jihād munādiyan, 8 Jumādah al-Ūlā 1423/1 January 2003, available online at http://tawhed. ws/r?i=749 (accessed on 4 February 2008).

4. Muhammad Hamidullah, The Muslim Conduct of State (Lahore: Sh. Muhammad Ashraf, 1987), 299. 
Based on this revelation, armed jihād is understood as a standing obligation until the end of the world and its aim is to fight non-Muslims until all lands submit under the rule of Islam. Thus, the only basis for Muslim and non-Muslim interaction is one of conflict. Muslims are hence not allowed to enter into any permanent peace agreement with non-Muslim countries. Any period of peace should not exceed ten years, i.e., the length of what is known as the 'Treaty of Hudaybiyyah' between the Prophet and the pagan Arabs of Mecca. ${ }^{5}$

Non-Muslim inherent hostility towards Islam. The Qur'ān constantly reminds Muslims about the supposedly hostile attitudes of non-Muslims, claiming that they will never be pleased unless all Muslims abandon their religion and follow the nonMuslim's way of life $(2: 109,120 ; 4: 89)$. They are portrayed as sharing a common hatred towards Islam, being never unceasing in their efforts to conspire against, subvert, or try to subjugate and fight it whenever the opportunity presents itself $(2: 9,105,217 ; 9: 8 ; 5: 82 ; 63: 7-8 ; 3: 69)$. They will commit treachery and all possible means to feed their vendetta against Islam (3:118-20; 2:75-7). Due to that, Muslims are enjoined to be wary and firm towards all non-Muslims $(48: 29 ; 5: 54 ; 63: 4)$. The hostile nature of the relationship between Muslims and non-Muslims is thought to be due to the fundamental differences between both communities, as the former is ostensibly based on full submission ('ubüdiyyah) to God only and the latter is based on submission to fellow humans or 'false' gods. ${ }^{6}$ Through this very narrow lens, there are admittedly plenty of historical precedents to support this view, such as the alliance between the pagan Arabs and the Jews against the Prophet, despite the latter being accorded special status as a 'People of the Book' (ahl al-kitāb) in Islam. Other examples include the peace treaties concluded between the abovementioned groups, the Crusades and the colonisation of Muslim lands in more recent times. More contemporary examples would point towards the supposed collusion between communists, polytheists and Christians against Muslims in Russia, China, Yugoslavia, Albania, India and Kashmir. ${ }^{7}$

The al-walā'(allegiance) and al-barā'(disassociation) doctrine. Al-walā' means total loyalty and allegiance to God only and all that pleases Him, while al-bara ${ }^{\prime}$ means total disassociation from everything that displeases God. Since only Islam and its followers please God, Muslims must have full loyalty to the teachings of Islam, actions that conform with it and fellow Muslims only. However, a Muslim's faith will not be complete by upholding al-walä' only. He must also practise al-barā', ${ }^{8}$

5. Majid Khadduri, The Islamic Law of Nations: Shaybani's Siyar (Baltimore: The Johns Hopkins Press, 1966), 16-17.

6. Sayyid Quțb, F̄̄ Zilāl al-Qur'ān (Beirut: Dār al-Shurūq, 1985), 3: 1586-7. See also his commentary on offensive jihād in ibid., 1431-52.

7. Ibid., 1593; Hizbut Tahrir, The Inevitability of the Clash of the Civilizations (London: Al-Khilafah Publications, 2002), 28-39.

8. Al-Qahțān̄̄, Al-Walā' wa'l-barā', 89-94, 137-46. 
This means that a Muslim must disassociate himself from everything related with kufr (disbelieving) and kuffär (infidels) (60:4; 19:49-1; 11:54-6; 43:26-8; 10:41). ${ }^{9}$ Muslims should not associate themselves with the kuffār so as to avoid anything that may dilute their identity and compromise Islamic principles. Because of this doctrine, together with the non-Muslim's inherent hostility towards Muslims, fraternity with them is strongly discouraged though is not prohibited outright $(3: 118-20 ; 8: 72-3$; $3: 28 ; 4: 89 ; 5: 51)$. To protect the faith and identity and in order to convey the beauty of Islam, Muslims are enjoined to always distinguish themselves from non-Muslims. Therefore, Muslims are required to avoid imitating non-Muslims' behaviour, dressstyles and observing or participating in their festivals (5:51). Living together with them in a Muslim country is strongly discouraged. Living in a non-Muslim country or travelling to one is only allowed under strict conditions, i.e. for the purpose of $d a$ 'wah (propagation), and with the assurance that the faith will not be compromised. A Muslim co-existing with the kuffār in a non-Islamic environment can be denied a place in Paradise in the Afterlife (4:97-9). ${ }^{10}$ However, Muslims are enjoined to offer kind treatment and establish justice for non-Muslims, providing that they avoid fraternising with them. Muslims are allowed to benefit from and learn non-Muslim knowledge; particularly in the field of science and technology (60:8-9). ${ }^{11}$

Some notes on this category. Due to this negative view of non-Muslims, it can be concluded that this school of thought requires Muslims to restrict and marginalise non-Muslim cultural or religious practices in the public sphere where non-Muslims predominate. This is either by limiting non-Muslim religious practices to private homes or their particular places of worship. Muslims living in non-Muslim countries should conversely segregate themselves socially so as to protect the purity of their faith and identity.

Proponents of this view agree that freedom of religion does not include the freedom for any Muslim to renounce Islam and convert to other religions. They also agree that the punishment of apostasy should be death as is any act regarded as blasphemous to Islam. Scholars who subscribe to this category agree, however, on the right of non-Muslims living in a Muslim country to practise their religion and culture in the private space. They also agree on the importance of Muslims living in a non-Muslim country to be religiously prudent in their social interaction with the larger non-Muslim community. On the other hand, the same scholars differ on the intricacies of the issue. Firstly, they disagree on the extent to which non-Muslims are

9. Ibid., 137-46.

10. Ibid., 224, 234, 246-77, 272-90, 306-9, 321-42; See also Shaykh Saalih bin Fawzaan AlFawzaan, "Al-Walaa' wal-Baraa'. Allegiance and Association with the People of Islaam and Emaan and Disassociation and Enmity with the People of Falsehood and Desbelief [sic] in Islaam)", Calgary Islamic Homepage, 1997, available at http://calgaryislam.com/imembers/pdf/ manhaj/16.pdf (accessed on 4 February 2008).

11. Al-Qahțānī, Al-Walā' wa'l-barā', 364-71. 
allowed to act in the public space. Secondly, they differ on the extent of segregation that Muslims living in a non-Muslim country should observe. Finally, there is no universal consensus on the use of armed jihād to ensure Islam's dominance above other religions and cultures. The negative impact these differences have on plurality and the diversity of faith and culture depends on how their proponents interpret the evidence of the Qur'ān and the hadīth.

\section{Islam and Plural Society: The Positive Viewpoint}

The second view holds that Islam promotes positive attitudes towards life in a plural society.

Diversity is natural. This view is based on the argument that Islam commands Muslims to embrace diversity because it is part of the law of nature that God Himself created. To support this position, they highlight the Qur'ān's numerous references to the diversity of nature. For example, the Qur'ān states that God created the different sexes and ethnic groups among mankind (30:22) that they might know and understand each other (49:13).

The Qur'ān constantly describes Muslims and non-Muslims as non-homogeneous groups, of different forms and colours. God, then, accords each one of them their own status and rules $(8: 72-5 ; 35: 32 ; 4: 95 ; 60: 8-9)$. In that respect, the Qur'ān allocates a special status to the People of the Book, by declaring the meat slaughtered by them as halāl, that it is also halāl to marry their women $(5: 5)$ and there are also different groups within the Peoples of the Book $(5: 82-3 ; 5: 69 ; 2: 62)$. The focus of Islam is not the homogenisation of a society into one culture, faith or identity but an observation of proper conduct so as to ensure that diversity will produce positive results. The diversity that Muslims are called upon to embrace extends to culture, religion and views. On the diversity of views, the Qur'ān commands Muslims to always seek for the best opinion (39:17-18) and this cannot be achieved unless there is a variety of opinions for Muslims to compare, contrast and eventually choose.

More pertinently, another verse explains that religious diversity is intentional (5:48). The verse explains that God could have made mankind as a single community or nation but He instead created the different ethnic groups, wherein each were given their own laws and way of life, so as to test who amongst mankind are truly committed to peace and the common good. The Qur'ān proclaims that differences among human beings will remain (11:118-19). Hence, it is neither possible, nor commanded, to make everyone believe in one faith (10:99).

The overall message of the Qur'ān essentially leads us to one important point: One ought to be careful with ideas that generalise Muslims or non-Muslims as one monolithic or homogeneous group. Such ideas are often reflected in a form of binary vision, which sees this complex phenomenon through a 'black-and-white' 
or 'us-versus-them' perspective only. Such generalist views also do not fit with the teachings of the Qur'ān because they produce stereotypes which portray all nonMuslims as inherently hostile, which is forbidden (49:12). Prejudice of this kind is not different from the misconception among some non-Muslims that all Muslims are 'terrorists' or 'fanatics'. It therefore is contradictory for Muslims to complain of being discriminated against by non-Muslims when the former, on the other hand, stereotype non-Muslims as being 'villainous'. Such double standards not only expose Muslims to criticism, but, more importantly, negate the very principles of justice and equity in Islam.

It is also important to understand both verses by understanding the particular context of their revelation. Al-Qurtubī and al-Ṭabarī cite a view from Mujāhid that the verse "[Your enemies] will not cease to fight against you [...]" (2:217) was revealed with regard to the Quraysh of Mecca and their extreme hostilities towards the Muslims. ${ }^{12}$ In other words, the verse has to be seen in the light of the historical contexts of the time. Thus, verses in the Qur'ān that call upon Muslims to disdain non-Muslims ought to be interpreted as referring to only non-Muslims opposed to the former's faith, as indicated in the verse "O ye who believe! Take not my enemies and yours as friends (or protectors)" (60:1).

From the perspective of Islamic hermeneutic methodology, the blanket view towards non-Muslims is arguably flawed because of its over-reliance on generalities ('āmmah) found in the Qur'ān, on the hadīths and the failure to observe the rule of takhșis (specification) as required and observed by Muslim exegetes. A maxim commonly held by Muslim scholars says 'there is no generality without exception' (lā 'āmmah illā wa huwā makhșūss). ${ }^{13}$ Thus, Muslim scholars suggest that no generalities ('āmmah) in the Qur'ān and the hadīths should be applied as the basis of a ruling or judgment before making an exhaustive search for other verses that could qualify its interpretation. ${ }^{14}$ By following this methodology, scholars would be able to determine the limits with regard to the scope in which such verse is to be applied. Consequently, a verse so qualified would have to be interpreted within that scope only. This is what the proponents of the previous category have emphatically failed to do.

In other words, verses of the Qur'ān about the character of non-Muslims must not be interpreted detached from its other verses and the practices of the Prophet

12. Muḥammad b. Aḥmad al-Qurtubī, Al-Jāmi` li aḥkām al-Qur'ān (Beirut: Dār al-Kutub al'Arabiyyah, 1988), 3 (pt. 3):32; Muhammad b. Jarīr at-Ṭabarī, Jāmi ‘ al-bayān fì ta' 'wīl al-Qur 'ān (Beirut: Dār al-Fikr, 1978), 2 (pt. 2):354.

13. Muḥammad b. 'Alī al-Shawkānī, Irshād al-fuhūl ilā tahqūq al-ḥaqq min 'ilm al-uṣūl (Beirut: Dār al-Kutub al-Islāmiyyah, 1999), 1: 475; Abū Ḥāmid al-Ghazālī, Al-Mustașfā min 'ilm al-uṣūl (Beirut: Dār Ihỵā’ al-Turāth al-‘Arabī, 1997), 2: 48.

14. Al-Shawkānī, Irshād, 1: 465. 
during his lifetime. ${ }^{15}$ The following are some examples from the life of the Prophet that would limit the generalities of the negative verses:

1. The Prophet was constantly protected by his uncle, Abū Țālib, who by popular historical account did not embrace Islam until his death. ${ }^{16}$

2. Under intense persecution by the Meccan people, the Prophet commanded his followers to seek refuge in Abyssinia, which was ruled by a Christian king, who was commended by the Prophet as a fair ruler who would not wrong any of his subjects. ${ }^{17}$

3. After the rejection of the Prophet's message in the city of Tā' if, he could not re-enter Mecca safely until Al-Muț'im b. 'Adī, a notable non-Muslim figure in Mecca, put him under his protection. ${ }^{18} \mathrm{Abū}$ Bakr, a companion of the Prophet, also received protection from a non-Muslim leader in Mecca. ${ }^{19}$

4. After the migration to Medina, the Prophet entered into a peaceful agreement with various non-Muslim Arab tribes. The Prophet maintained his commitment to the agreement until his death. ${ }^{20}$

5. The Prophet launched a punitive military operation against the Meccans, which led to the fall of Mecca. This was in reaction to the Meccans attacking a non-Muslim tribal ally of the Prophet, in blatant violation of the 'Treaty of Hudaybiyyah', which contained clauses favourable to the Meccan pagans and specifically forbade the parties involved to attack each other or their respective allies for a period of ten years..$^{21}$

Peaceful co-existence, tolerance and respect for other faiths. Islam is essentially a religion of peace. This is, firstly, by virtue of its name that is derived from the verb aslama, which means, 'to submit', 'to surrender'. It is derived from the root word salm or silm, which means 'peace', 'security'. ${ }^{22}$ Secondly, the greetings that Muslims are enjoined to convey to others is al-saläm 'alaykum (pronounced

15. Al-Shawkānī, Irshād, 1: 532-4; Abū Isḥāq al-Shātibī, Al-Muwafaqāt fĩ uṣūl al-fiqh (Beirut: Dār al-Ma'rifah, 1997), 3: 97-8, 233-5.

16. Sayf al-Raḥmān al-Mubārakpūrī, Al-Raḥ̄̄q al-makhtūm (Riyadh: Maktabah Dār al-Salām, 1995), $123-4$.

17. Ibid., 99-100.

18. Ibid., 140.

19. Sa‘īd Hawwa, Al-Asās fi'l-sunnah (Al-Sīrah al-nabawiyyah) (Cairo: Dār al-Salām, 1985), 3: 1563.

20. Al-Mubārakpūrī, Al-Raḥ̄̄, $197-8$.

21. Ibid., 388-9.

22. Al-Mu'jam al-Wāsit (Cairo: Majma‘ al-Lughah al-'Arabiyyah, n.d., 3rd ed.), 462-3; Rohi Baalbaki, Al-Mawrid: A Modern Arabic-English Dictionary (Beirut: Dār al-'Ilm li’1-Malāyīn, 2001), 107, 641; J.M. Cowan (ed.), The Hans Wehr Dictionary of Modern Written Arabic (New York: Spoken Languages Services, 1976), 424-5. 
'Assalaamualaykum'), which means in fact 'peace be upon you'. Furthermore, the Qur'ān prefers peace to conflict (8:61). Fourthly, history has proven that Islam is more convincingly accepted during times of peace and through peaceful means. The 'Treaty of Hudaybiyyah' serves as a powerful demonstration of this, as large numbers of people converted to Islam in the two peaceful years that followed the conclusion of that accord - almost equalling the number of converts in the 19 preceding years of the Prophet's mission. History has also shown that Islam has the potential to spread rapidly via peaceful methods as it did in the Malay Archipelago and in China. Therefore, establishing and maintaining peace and the use of peaceful means to convey the message of Islam is of paramount importance. On that note, peaceful co-existence with other faiths and cultures is enjoined upon Muslims. It is a means as well as a manifestation of their commitment to peace and helps spread the message of Islam more effectively.

Because diversity is the natural state of the universe, tolerance becomes a fundamental teaching of Islam. This is manifested through Islam's commands to respect other faiths, to avoid interfering in matters concerning another religion (109:1-6), prohibitions against any form of compulsion and coercion in faith (2:256, $272 ; 10: 99)$ and rebuking or insulting other faiths $(6: 108)$, which becomes the basis for peaceful co-existence of various religions in a society. Moreover, Islam requires the acceptance of a religious faith based on free choice (18:29). Intolerance in a plural society, in turn, will invariably produce conflict and will ultimately frustrate the claim that Islam is a religion of peace.

Since conflict will produce only hardship and difficulties, intolerance contradicts also another important characteristic of Islam - that Islam is a religion of simplicity, practicality and ease $(2: 185 ; 5: 6$; and $22: 78)$. There is evidence from the hadith that reinforces the qur'annic message of tolerance and practicality, such as in the Prophet's saying: "Make it [i.e. the Islamic obligations] convenient and do not make it difficult, tell them the good news and do not make them run away" (narrated by al-Bukhārī).

We have seen earlier how it has been claimed by the extremists that verses in Chapter 9 of the Qur'ān supposedly abrogated all verses on jihād as a form of self-defence, patience and tolerance towards non-Muslims and established instead conflict as the basis of their relationship with Muslims. This claim, however, is rejected by the majority of Muslim scholars, because there is no evidence to support it. With regard to verse 5 of Chapter 9 , there is no mention about it abrogating earlier verses on defensive jihād according to al-Ṭabarī and Ibn Kathīr - two of the most prominent exegetes of the Qur'ān. In fact, al-Qurtubī reported that some scholars - among them al-Ḍaḥhāk - were of the view that this verse, which says, "slay the idolaters wherever you find them, and take them captives and besiege 
them and lie in wait for them in every ambush", was abrogated by other verses in the Qur'ān (47:4). ${ }^{23}$

Similarly, regarding the reportedly hostile attitudes of non-Muslims towards Islam, the prevalent opinion among Muslim scholars is that verses on jihād cannot be interpreted independently from each other. They are to be studied together in order to derive the true understanding of jih $\bar{a} d$ in Islam. In this respect, Muslim scholars have agreed that verses which are general or unconditional, such as the command to fight the pagans everywhere and at all times $(9: 5,14,36)$, must be interpreted as conditional, i.e. as a command to fight aggressors only $(2: 190,194)$. Thus, the meaning of verses from Chapter 9, which are unconditional, would mean that Muslims are exhorted to fight non-Muslims only when attacked by them first.

In addition, classical Muslim scholars have argued that verses which called upon Muslims to wage unconditional, armed jihād against all non-Muslims refer specifically to the Arab pagans of the time of the Prophet. Some scholars were more specific by saying that the verses were revealed exclusively in respect to the people of Mecca or rather, the tribe of Quraysh who had been in a prolonged state of war against Muslims through unprovoked aggression and violence, which continued even after Muslims migrated to Medina. Despite entering into various treaties with the Muslims in Medina, the Quraysh and other pagan Arab tribes repeatedly violated them. It became clear, therefore, toward the end of the Prophet's mission, that peaceful relations with those tribes were impossible, leading to the instruction in that chapter to denounce the treaties and wage war. Al-Nawawī, furthermore, wrote that the verse did not refer to the 'People of the Book' (i.e. Jews and Christians) and thus, it is inappropriate to apply these verses indiscriminately to all non-Muslims today. ${ }^{24}$

Islam should hence not be made the cause of difficulty for Muslims to co-exist with non-Muslims by demanding from them to segregate or to be segregated from the latter. We have heard time and again how the early Islamic communities in Mecca and Medina existed as plural societies, through the peace agreements signed

23. Wahbah al-Zuhaylī, Al-Tafsīr al-munīr fì̀'l- 'aqīdah wa 'l-sharī'ah wa'l-manhaj (Damascus: Dār al-Fikr, 1991), 10: 110, 175-8; Louay Safi, "Peace and the Limits of War: Transcending the Classical Conception of Jihad. Chapter 4: War of Domination", available online at http://lsinsight. org/articles/2001/peace-war/index.htm (accessed on 4 February 2008); al-Qurtubī, Al-Jāmi ‘ 4 (pt. 8): 47; Ismā‘̄il Ibn Kathīr, Tafsīr Ibn Kathīr (n.pl.: Dār al-Fikr, 1980), 2:338; at-Ṭabarī, Jāmi ‘ al-bayān 6 (pt. 10): 80-1 and 13 (pt. 26): 40-4; al-Shāṭib̄i, Al-Muwafaqāt 3: 97-8; al-Ghazālī, Al-Mustaşā 2: 50 .

24. Al-Zuhaylī, Al-Tafsīr, 10: 108-9; Muḥammad Khayr Haykal, Al-Jihād wa'l-qitāl fi'l-siyāsah alsharī'ah (Beirut: Dār al-Bawādir, 1996), 3: 1456-7; al-Qurtubī, Al-Jāmi`, 4 (pt. 8): 42; at-Ṭabarī, Jāmi ‘ al-bayān 6 (pt. 10): 61, 77; Ibn Kathīr, Tafsīr 2: 338; Muhy al-Dīn al-Nawawī, Al-Minhaj: Sharh Ṣaḥ̄h Muslim (Beirut: Dār al-Ma'rifah, n.d.), 1: 156; see also Muștafāal-Bugha, and Muhyy al-Dīn al-Mistū, Al-Wāfì: F̄̄ Sharh al-Arba'īn al-Nawawiyyah (Damascus: Dār al-'Ulūm al-Insāniyyah, n.d.), 47 . 
between the Prophet and the various pagan Arabs and Jewish tribes then living in that city.

Islam is inclusive, not exclusive. One of the important traits for harmonious living in a plural society is that of being inclusive. 'Inclusive', in this sense, refers to the openness to accept others or what comes from others, and not rejecting them purely because they are from a group that appears to be different from ourselves. Inclusivity is founded on the belief that positive universal values exist in various groups and communities. People and their views are to be accepted or rejected purely based on merit, not on the basis of their origins. There are many indications that Islam requires Muslims to be inclusive so that they can help achieve a harmonious and peaceful co-existence in multicultural societies. God sent Muhammad as a 'mercy for all creations' $(21: 107)$. As this indicates that Islam is an inclusive religion, it is a tacit call for Muslims to be inclusive in their social conduct.

Islam also commands Muslims to defend those who are oppressed or persecuted irrespective of their race or religion. The Qur'ān also states that God will ensure that groups of people who reject and work to stop evil and aggression will repeatedly emerge until all the mosques, churches and other places of worship are saved from destruction (22:40). This indicates that rejecting evil deeds does not ensure the safety of Muslims only, but of all faiths. This again points to the idea that Islam is an inclusive religion, which seeks to safeguard the rights of all members of a society and is in line with Islam being a religion of mercy for all mankind.

Islam also encourages Muslims to have an open attitude to positive ideas from foreign sources, to learn from the experiences of others, and to strive toward what is good. These are important prerequisites in promoting progress and development. Knowledge is regarded as something that should be sought after regardless of its source of origin. The Prophet has once said that "wisdom is the lost property of the believers. Whoever finds it is entitled to it." Early Muslim scholars encouraged Muslims to seek knowledge in every part of the known world, 'even from as far away as China', because that nation was then a thriving civilisation from which Muslims could derive much knowledge. Western scholars have also acknowledged that Muslims were responsible for preserving and subsequently transmitting to the West much of the intellectual heritage of the Ancient Greek and Roman civilisations. This would not have been possible had the Muslims then not embraced inclusivity.

Like other religions, Islam requires its followers to preserve its principles and fundamentals. Some of these distinguish Islam from the other faiths and provide Muslims with a distinct identity. Nevertheless, Islam does not call for such absolute forms of exclusivity which would detach or separate Muslims from other communities, causing them to reject anything that comes from 'the Other', just because this 'Other' happens to confess another faith. Such a positive attitude would 
not have been possible if the teachings of Islam were fundamentally incompatible with a plural society.

The rule of non-assimilation. Moreover, Islam does not command Muslims to forcefully assimilate non-Muslims into their cultural or religious realm. In fact, Islam guarantees non-Muslims the freedom to practise their religion and to maintain their culture. Denying such rights or forcing non-Muslims to relinquish their religious beliefs and cultural practices is regarded as a serious breach of Islamic injunctions. One of the key principles of social interaction laid down in the Qur'ān is "for you, your religion and for me, mine" (109:1-6; 44:15).

When the Prophet entered into a treaty with various Jewish and pagan Arab tribes, the clause stated, "verily, the Jews shall be considered as a community (ummah) along with the Believers [i.e. the Muslims]; for the Jews, their religion, and for the Muslims their religion [...]". ${ }^{25}$

An agreement between the Prophet and the Arab Christians of Najrān, in the south of the Arab Peninsula, provides more details:

From the Prophet Muhammad to the bishop Abū'l-Hārith, to the bishops of Najrān, and to their priests and those who follow them, as well as to their monks: To them belongs all that I place in their hands, whether little or much, their oratories, and their monasteries; [guaranteed by] the protection of Allāh and His Messenger. No bishop will be removed from his episcopal see, no monk from his monastery, no priest from his vicarage. None of their rights, nor any of their powers will be changed, nor anything to which they are used to. On this, the protection of Allāh and His Messenger is guaranteed for ever, as long as they behave sincerely, and act in accordance with their duties. They will neither be subjected to oppression, nor shall they be oppressors themselves. ${ }^{26}$

Similar - with some additions - can also be found in agreements between the Prophet and the dwellers of the St Catherine monastery in Sinai. The Prophet's practice was later emulated, for example, 'Umar b. al-Khatțāb, the second caliph after the Prophet, in his agreement with the Christians of Jerusalem ${ }^{27}$ and in Khālid b. al-Walīd's agreement with the Christians of 'Anat. ${ }^{28}$

Based on the works of classical and contemporary Muslim scholarship, the rights of non-Muslims living in a Muslim society can be summarised as follows:

1. Non-Muslims are free to perform their rituals and acts of worships in accordance with their own religion.

25. Muhammad Hamidullah, The Life and Work of the Prophet of Islam (New Delhi: Adam Publishers, 2004), 157-60.

26. Ibid., 470 .

27. Ibid., 115 .

28. Ibid. 
2. Non-Muslims have the right of protection and security with regard to life, property, belief, and culture. Muslims have a duty to fight those who threaten this security.

3. Non-Muslims are free to have their own religious or cultural celebrations and festivals.

4. Non-Muslims should be allowed to build and maintain their places of worship to facilitate their religious activities.

5. Non-Muslims are free to propagate their religion and organise missionary works as long as they are conducted in a civil manner.

6. Non-Muslims are free to bring up their children according to their culture and religion. They can have their own vernacular education system.

7. Non-Muslims should have the right to judicial autonomy. This means that they are entitled to their own personal law to regulate matters related to marriage, divorce, inheritance and custody of children. They can also choose to settle disputes in accordance to their religion and culture $(5: 43,47)$. Special courts can be established for them and judges can be appointed from among them to adjudicate cases. ${ }^{29}$

8. Non-Muslims are allowed to consume food and drink that is permissible by their religion but forbidden to Muslims, such as pork and alcohol. ${ }^{30}$

9. Non-Muslims enjoy equal civil rights and the same protection enjoyed by Muslims, i.e. freedom of expression, political participation and association and equality provided for by the law.

The commitment to this non-assimilation rule was institutionalised during the Ottoman Empire in the form of what is known as the 'millet system'. In accordance with this practice, each religious community was regarded as an "autonomous social unit that enjoyed administrative and legal independence. The millets were headed by clergymen who were responsible for the civil status, judicial process, church property, education, charity and even tax collection." ${ }^{11}$ The system allowed peaceful co-existence and preservation of religious and cultural identity of various religious communities under one single polity.

Some notes on this category. Differences of opinion, however, also exist amongst Islamic proponents of plural societies. What follows are examples of such points

29. Ahmad Yousif, "Islam, Minorities and Religious Freedom: A Challenge to the Modern Theory of Pluralism”, Journal of Muslim Minority Affairs 20, no. 1 (2000), 36-7; See also Muhammad Fathī 'Uthmān, Huqūq al-insān bayn al-sharī'ah al-islāmiyyah wa'l-fikr al-qānūn al-gharb̄̄ (Beirut: Dār al-Shurūq, 1982), 106-7; Abū'l-A'lā al-Mawdūd̄i, Al-Hukūmah al-islāmiyyah (Cairo: AlMukhtar al-Islāmī, 1980), 196-211.

30. A. Rahman I. Doi, Orang bukan Islam di dawah undang-undang syariah (Kuala Lumpur: Dewan Bahasa dan Pustaka, 1992), 74.

31. Yousif, "Islam, Minorities and Religious Freedom”, 37. 
of contention. It is important to understand some of those differences because they will illustrate the extent of tolerant practices propagated by the sub-groups in each category. This allows us to see the clear dichotomy between the contrasting viewpoints and the finer variations within the continuum.

Firstly, the majority of those who hold the positive viewpoint are tolerant of people of other religions and cultures. However, they maintain the view that Islam is the only true religion and way of salvation, that the Qur'ann is the final revelation to 'complete' and 'correct' other holy books and, finally, that its teachings are superior to the others. A minority, on the other hand, holds that adherents of other faiths are 'capable' of achieving salvation, God's approval, enabling them to secure a place in heaven by truly following Isläm (here in the sense of belief in monotheism) through belief in one God. They would need to fully submit to Him and obeying His commandments which thus would not necessarily imply that they are members of the religion that was revealed to Prophet Muhammad..$^{32}$ 'Tolerance' - according to the former 'school', would therefore only mean putting up in the short term with the others, while still actively seeking to convert them in the long term. For the latter, however, 'tolerance' would involve truly respecting the faith of others, with the acknowledgement that these beliefs are equally valid. These two different positions produce various degrees of freedom and forms of social interaction. The latter would provide more space and tends to be more relaxed, ultimately arriving at a 'live and let live' attitude towards the non-Muslim 'Other'.

Secondly, although the majority of thinkers assert that Islam forbids any form of compulsion and every individual is free to choose one's faith, they make the significant exception in terms of a Muslim converting to another religion, thus committing apostasy. With regard to this issue, they appear to be subdivided into three lines of thought: (i) Apostasy constitutes a serious sin and, after having been convicted by a shari 'ah court and given opportunity to 'repent' but failing to do so, this sin would be punishable with the death penalty; (ii) Apostasy is a grave sin and, after having been convicted by a shar ' ' $a$ h court and given opportunity to 'repent' but failing to do so, this sin would be punishable, however the ultimate form of punishment would be left to the discretion of the authorities; and (iii) Apostasy is a sin, but no punishment in this world can be imposed, because any form of punishment is tantamount to coercion. ${ }^{33}$

32. Mahmut Aydin, "Religious Pluralism: A Challenge for Muslims - A Theological Evaluation", Journal of Ecumenical Studies 38, no. 2-3 (Spring-Summer 2001), passim; Sohail H. Hashmi, "The Quran and Tolerance: An Interpretive Essay on Verse 5:48", Journal of Human Rights 2, no. 1 (March 2003), 81-3, 101; Ali S. Asani, "Pluralism, Intolerance, and the Qur' an", The American Scholar 71, no. 1 (Winter 2002), 54.

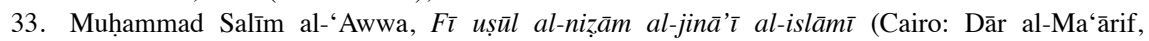
n.d.), 150-4; IslamOnline.Net, "Apostasy and the Freedom of Religion”, Islam Online Special Folder, available online at http://islamonline.net/English/contemporary/2006/04/article01.shtml (accessed on 4 February 2008). 
Thirdly, while all of the scholars agree that rights and freedoms are neither unlimited nor unconditional, they differ on the exact details of the conditions imposed on religious and cultural expressions in public. Their views are dependent on how they balance the right for freedom and other social and political interests. For example, some scholars do not allow the building of a church or temple in Muslim-dominated areas, so as not to 'offend' Muslims, therefore preserving - in their view - social harmony, while some other scholars do not allow any kind of criticism of Islam in public by non-Muslims. ${ }^{34}$

Altogether, the proponents of this opinion do not argue that accepting diversity will completely eliminate conflict between various groups. Diversity, indeed, will cause clashes of interest. Whenever there are different priorities, each party will strive to champion its own interests above those of the others, which would only be normal and can hardly be avoided. However, what appears to be important to the scholars is to ensure that negative outcomes are avoided. This process should be managed to produce mutually beneficial resolutions and to foster a better understanding of each other's aspirations.

\section{The Spectrum of Views in a Continuum}

Based on what has been said above on the two contrasting 'negative' and 'positive' positions, a preliminary spectrum of views in a continuum can be developed as illustrated in the large chart below. The chart is divided in the middle into two equal parts. The left section represents the negative position first described while the right section represents the positive position. In view of the differences within each position, it could be argued that either position can be further subdivided into two categories - minimum and maximum. Thus, a spectrum of four views can be illustrated from the left to the right.

The continuum starts from extreme left which is the maximum negative position, followed by the minimum negative position close to the middle. It then continues to the middle and into the second position with a minimum positive position and ends at the extreme right, which represents the most positive position towards a plural society. Elements that characterise the four views in the continuum are described in the four columns underneath. Each represents one view from left to right.

The chart also provides an illustration of the attitudes of all the four views on two issues: (i) the assimilation of non-Muslims in a Muslim country and (ii) the segregation of a Muslim minority in a non-Muslim country from the host society.

34. Yousif, "Islam, Minorities and Religious Freedom", 35-6; Yūsuf al-Qaraḍāwī, "Ghayr almuslimīn fî̀l-mujtama“ al-islāmı̄”, available online at http://qaradawi.net/site/topics/article. asp?cu_no=2\&item_no=442\&version=1\&template_id=93\&parent_id=1 (accessed on 4 February 2008). 
'Assimilation' here refers to the process whereby a minority group in a society absorbs the prevailing culture in a society. As for segregation, it refers to the process of separating two or more distinctive groups from each other to maintain the way of life of each group from polarisation by the others.

The movement of the position from the 'hardest' to the 'softest' in both situations is from left to right as indicated by the arrow. This means that the view at the extreme left position would tend to support or promote 'hard' assimilationist policies on nonMuslims in order to exert Islam's authority and supremacy above all other ways of life and ideologies (based on Qur'ān 69:9; 2:193). It would also take the strongest position for segregation of minority-Muslims in non-Muslim countries in order to protect their identity and religious practices and as an expression of unwillingness to submit to any authority other than Islam.

Since a predominant Muslim society and a predominant non-Muslim society constitute two different contexts, the needs, interests and objectives to be protected, pursued or achieved are different. This explains the two contrasting positions by the same view in the two contexts. Muslims who hold to the view located on the left of the continuum often view secular Muslim regimes as 'un-Islamic', thus belonging to the same category as non-Muslim countries. Their attitude, in this context would be closer to the position taken for minority Muslims. They would tend to gravitate towards social segregation in order to protect themselves from the 'evils' of a secular society, which often resembles a Western non-Muslim lifestyle.

Due to the positive attitudes of the last two views on plural society, it is not difficult to anticipate their soft position on assimilation and segregation in the two contexts; with the softest position located on the extreme right. A 'soft' assimilationist position is due to the importance given to the idea of freedom guaranteed by Islam, based on the qur'ānic notion of 'no compulsion in religion'. According to this view, da 'wah must be done "with wisdom and beautiful preaching", which would mean to "argue with them [i.e. the non-Muslims] in ways that are best and most gracious" (16:125).

Similarly, the 'soft' attitude towards segregation is motivated by the belief that Islam does not encourage social exclusivism because the Prophet has said, "a Muslim who socializes with others and is patient with their misdeeds, is better than a Muslim who does not socialize with others and is not patient with their misdeeds" (narrated by al-Tirmidhī) and that the beauty of Islam is better projected through positive engagement and constructive contribution to the society that Muslims live in.

It could be said that views which gravitate towards the left axis of the chart tend to be more intolerant towards non-Muslims. The opposite is true for those which gravitate to the right. It is not true, however, that the intolerance towards diversity in a plural society is synonymous with the left position because, in reality, there are many instances of intolerance by the holders of the rightmost position (especially if 
they are in the position of power), towards those who disagree with them or those who hold to the spectrum of view in the left. Kemal Atatürk's policy of enforced westernisation and secularisation of Turkish Muslims and its continuance by secular elements of the contemporary Turkish elite is one example of this phenomenon.

\section{Reasons behind the Two Contradicting Interpretations}

The two positions on the issue - positive and negative - point to a fact that it is possible to interpret Islam in ways that come across as contradictory to each other. In fact, there have been many such contrasting interpretations throughout the history of the religion. Understanding the reasons behind this will enhance one's understanding of Islam and the internal dynamics within the Muslim ummah. They also provide answers to those who are fascinated with the fluidity of the interpretation of Islam in history and in contemporary situations.

This article suggests that there are three reasons behind the two contrasting positions of Islam and plural society. While these reasons are not exhaustive, they are sufficient to explain how Islam can be interpreted differently on a single issue.

\section{The nature of the religion}

Muslims believe that Islam is a religion for all mankind to prepare them for the Day of Judgement. To ensure Islam's relevance across time and space, the Qur'ān was purposefully revealed through verses that are non-muhkamāt (non-definitive). They are rendered ambiguous, thus allowing for various interpretations. This provides flexibility for Muslim scholars to adapt the teachings of religion in accordance to changing contexts. They also allow Muslim scholars to deduce different rulings on one issue and hence provide opportunities to anyone who needs to make various considerations, or choose an opinion that he feels is closer to the truth and the objectives of sharì 'ah vis-à-vis his context. This is because certain opinions may be suitable at a certain time or a certain situation but not at another. ${ }^{35}$

Admittedly, such ambiguity also provides an opportunity for interpretations that justify intolerance and hatred. For example, the Qur'ān provides two types of verses on armed jihād: (i) conditional verses specifying armed jihād against the infidels, which can only be waged if Muslims are under attack (9:5, 4, 29, 36, 73, and 123); (ii) unconditional verses calling Muslims to wage armed jihād against all infidels $(2: 190,193-4 ; 4: 175 ; 22: 39-40)$.

In an attempt to reconcile those verses, some Muslims, especially the 'jihadists', who subscribe to the first negative position, invoke the abrogation argument. They argue that the unconditional verses abrogate all previous verses on armed jihād because they were revealed at a later period. This then perpetuates the misunder-

35. Yūsuf al-Qaraḍāwī, Al-Khașā'iș al- 'āmmah li'l-Islām (Cairo: Maktabah Wahbah, 1977), 231-2. 
standing that the primary basis of a relationship between Muslims and non-Muslims is one of war.

The above view is in contradiction to the view held by the majority of Muslim scholars who reject the abrogation argument of the 'jihadists' because there is no strong evidence that the verses above were revealed to nullify the other revealed texts, as explained in the second positive position.

\section{A crisis in the mind}

The term 'crisis in the mind' was coined by Abdul Hamid Abu Sulayman in his book entitled Crisis in the Muslim Mind. It refers to a state in the Muslim mind that has lost the ability to "understand what is really important, distinguish between what is fundamental and absolute and what is temporary and limited; or even appreciate what is essential and what is a matter of performance and style" ${ }^{36}$ The result of this weakness is that Muslims either accept the past with all peculiarities or they reject it entirely with all its values. The mind becomes stagnated due to its inability to take a critical look at the legacy of Islam's history. ${ }^{37}$ The most extreme left negative position in the continuum (produced in our chart) is one example of this 'crisis'. The proponents today fall into intolerant interpretations because they fail to understand the context on which the opinions of traditional Muslim scholars hundreds of years ago were built in offering Islamic viewpoints, perspectives or solutions to various issues and problems.

One example is the idea of Dār al-Islām (lit. 'Abode of Islam') and Dār al-Harb (lit. 'Abode of War), formulated by classical Muslim scholars. In their mind, Dār al-Isläm refers to an area ruled by a Muslim ruler and where the shari 'ah is the law of the land. In contrast, a land is considered as Där al-Harb when it is ruled by nonMuslims or when the shari ' $a$ h is not recognised or applied. They are of the view that the use of Där al-Harb as a terminology to describe non-Muslim lands by classical Muslim scholars suggests that all such lands should be considered as enemies until they come under the rule of Dār al-Islām. The wholesale application of this concept in today's world without recognising it as time-bound, and the juxtaposition of the concept with the idea of $j i h \bar{a} d$ as a perpetual war against non-Muslims, strengthens their binary perspective - 'either you are with us or against us'. This contributes to shaping a negative attitude towards all non-Muslims.

\section{Context}

The problem of intolerant interpretations of Islam is two-fold: the misinterpretation of the text and the opportunity and contexts that provide for such (mis)interpretations.

36. Abdul Hamid Abu Sulayman, Crisis in the Muslim Mind (Herndon: The International Institute of Islamic Thought, 1993), 28.

37. Ibid., 29. 
In the case of acts of violent intolerance against non-Muslims and Muslims viewed as apostates practised today by 'jihadists', most of them occur within an environment of prolonged backwardness in terms of living standards as well as lack of freedom in the political domain. The secular and nationalist elites who rule such countries today are usually blamed for being corrupt and having failed their people. Disadvantaged Muslims, therefore, turn to Islam for answers to their predicament. In the process, some fall into violent extremism due to a misunderstanding of the religion, while others are arrested and tortured for being part of the opposition to the establishment. ${ }^{38}$

Muslims all over the world also share a deep sense of frustration with the injustices that they feel are inflicted by the major (non-Muslim) powers on Muslims by sponsoring their corrupt rulers at the expense of domestic freedom and development. ${ }^{39}$ Various scholars have pointed out that the uneven foreign policy of the United States in the Middle East, especially vis-à-vis Israel and the Palestinian Arabs, along with the war in Iraq, have contributed to the increased radicalisation among the Muslim youth. These views seem to help to reinforce the Muslims' historical experience of being at the receiving end of brutal treatment during the colonial period and the Crusades by actors who were largely non-Muslims, leading to the view that all kuffär (disbelievers) are inherently hostile towards Islam.

Whether it is the above-referenced historical contexts which influenced 'jihadists' to propagate hatred and intolerance or if they are merely using them to influence others to further their cause, both highlight the crucial role that grievance plays in fuelling sectarian violence. It is important to note here that some 'jihadists' may be so committed to their ideas that nothing can change their minds. Their support base can be diminished, however, if the breeding ground for their ideas is eliminated.

38. Amin Saikal, Islam and the West: Conflict or Cooperation? (New York: Palgrave, 2003), 129-42; John E. Mack, "Looking Beyond Terrorism: Transcending the Mind of Enmity", in: Chris E. Stout (ed.), Psychology of Terrorism (London: Praeger, 2002), 1: 175; Aftab Ahmad Malik (ed.), With God on Our Side: Politics and Theology of the War on Terrorism (Bristol: Amal Press, 2005), 85-96; Yūsuf al-Qaraḍāw̄̄, Islamic Awakening Between Rejection and Extremism (Herndon: The American Trust Publication and The International Institute of Islamic Thought, 1991), 53-9, 623; Fawaz A. Gerges, The Far Enemy: Why Jihad Went Global? (New York: Cambridge University Press, 2005), 61-7, 80-2; Jessica Stern, Terror in the Name of God: Why Religious Militants Kill (New York: HarperCollins, 2003), 3-8, 32-62, 107-36.

39. Sharif Abdullah, "The Soul of a Terrorist: Reflections on our War with the 'Other'", Psychology of Terrorism 1 (2003), 139; Clark McCauley, "Psychological Issues in Understanding Terrorism and the Response to Terrorism", Psychology of Terrorism 3 (2005), 10; B. Knowlton, "How the World Sees the United States and September 11", International Herald Tribune (20 December 2001), 1, 6; John L. Esposito and Dalia Mogahed, "What Makes a Muslim Radical?", Foreign Policy, November 2006, available online at http://foreignpolicy.com/story/cms.php?story_ id=3637\&page $=4$ (accessed on 4 February 2008); John L. Esposito, "Out of the Cycle of Ignorance”, The Guardian (7 July 2006), available online at http://guardian.co.uk/attackonlondon/ comment/story/0,,1814725,00.html (accessed on 4 February 2008). 
In this sense, the persecution and discrimination of Muslims backed by the powers of the state will provide the justification to invoke the 'qur'ānic injunction' of 'an eye for an eye', which often means intolerance for intolerance.

\section{Conclusion and Recommendations}

This article has attempted to present and identify two contrasting perspectives, i.e. negative and positive viewpoints, on Islam and plural society. From these two perspectives, two other variations are identified (referred to as 'maximum' and 'minimum', respectively). Each of them makes up a spectrum of views within one continuum. For the sake of understanding better the variations, we have developed a table that illustrates the spectrum of views in a continuum (see below). Applying it to the issue of assimilation and segregation, eight other variations of positions have been identified and explained.

\begin{tabular}{|l|c|c|c|c|}
\cline { 2 - 5 } \multicolumn{1}{c|}{} & \multicolumn{2}{c|}{ Negative perspective } & \multicolumn{2}{c|}{ Positive perspective } \\
\cline { 2 - 5 } \multicolumn{1}{c|}{} & Max.negative & Min.negative & Min.positive & Max.positive \\
\hline Assimilation & Hardest & Hard & Soft & Softest \\
\hline Segregation & Hardest & Hard & Soft & Softest \\
\hline
\end{tabular}

Admittedly, there could be even more variations, because only a more refined analysis would be able to identify other shades of views and opinions from various perspectives. A maximum-minimum categorisation within each perspective does not truly reflect the diversity that exists in each one. However, it is not the objective of this article to identify all possible categories or to offer a near-perfect picture of the differences. The primary objective here is to provide a broad picture of the situation that reflects the existence of diversity and dynamism within Muslim thought. Furthermore, space constraints do not allow for a full investigation to be conducted.

Although the article does admit that the ideas which promote extreme intolerance and justify violence in order to assert Islam's supremacy over others could be churned from Islam's primary sources, along with other internal factors, it is important to note that Muslims who fall into such extremism have historically always been regarded as being on the outside fringes of the Muslim ummah, or even as heretics, and thus cannot be taken as representative of the whole.

From a theological point of view, too, one can take heart in the promise that individuals or groups will always emerge from the ummah who will stand up against the misguided fringe and strive to correct or reform the community, as promised by God in the qur'ānic verse: "We have, without doubt, sent down the Message; and We will assuredly guard it [from corruption]" (15:9). The Prophet himself 
declared that "there will always be a group from amongst my ummah who will manifest the truth; no harm will come to them from those who have forsaken them until God shall make manifest His will while they [the extremists] remain in that state" (narrated by al-Bukhārī). This does not mean that Muslims should just leave this matter to God.

On the contrary, Muslims should actively strive to behave in a manner becoming of a people privileged to be God's vice-regents on Earth and to protect the sanctity of His religion from deviations and intolerance. At the same time, the nature of the religion of Islam and the historical experience means that there will always be a segment within the ummah that will display such damaging intolerance. They will remain a regrettable feature of both human and Muslim history for all time. A more practical objective would be to ensure that such groups remain on the outer fringes, unable to dictate the agenda of the day, instead of trying to eliminate them totally, which is difficult if not impossible. This can only happen if the majority of Muslims who are committed to a positive and tolerant Islam stand up and speak up for their beliefs against bigotry. This is the only way that the voice of moderation and tolerance in the ummah can prevail.

As mentioned before, however, the problem of (mis)interpretation is not due to the text alone but also its contexts. Therefore, in addition to promoting the voice of moderate Muslims, the historical antecedents that facilitate and are being manipulated for extremist interpretations of Islam must be addressed also. This requires some form of collaboration between Muslims and non-Muslims on the issue. It also requires the political will of the powers-that-be to address the root causes of the grievances which constitute an opportunity for extremist Muslims to seize and exploit the issues in order to further their cause. 


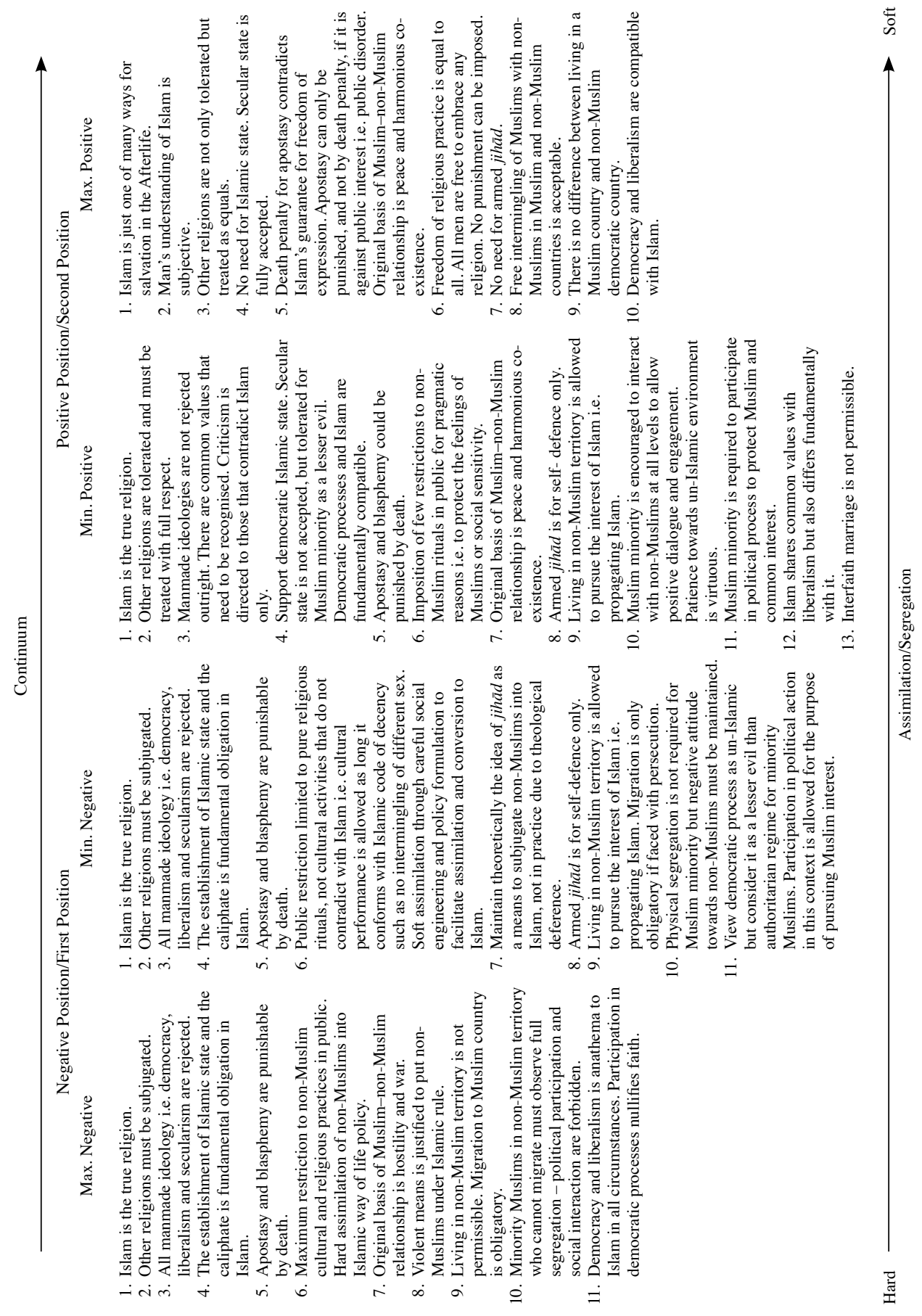

